\title{
The Effect of Aeration on River Water Receiving Industrial Discharges to Its Quality and Toxicity
}

\author{
Indah R S Salami ${ }^{1, *}$, and Dea Putri Pradita ${ }^{1}$ \\ ${ }^{1}$ Environmental Engineering, Environmental Technology and Management Research Group \\ Faculty of Civil \& Environmental Engineering, Institut Teknologi Bandung. Jalan Ganesha no. 10 Bandung, \\ 40132, West Java, Indonesia
}

\begin{abstract}
Citarum River in West Java Province was an important river that supported more than 25 million people in the region. It was considered highly polluted by many sources of wastes. This study was aimed to evaluate the effect of aeration process on river water quality and toxicity in Citarum tributary receiving industrial wastes as river restoration alternative. Three types of aeration methods namely mechanical, hydraulic, and diffused air were studied in laboratory scale. Water quality parameters analyzed were TSS, TDS, COD, nitrate, phosphate, nitrite, phenol, and acute toxicity LC50 96 hrs on Daphnia magna was tested to obtain TUa value. Results showed TUa of water samples collected at daytime was $0.467 \pm 0.12$, whereas night time water samples resulted higher toxicity of TUa $1.36 \pm 0.3$. Aeration of daytime river water by diffuser, mechanical aeration, and cascade aeration, reduced toxicity to TUa of $0.01 \pm 0.002,0.08 \pm 0.04$, and $0.30 \pm 0.2$ respectively. On the other hand, aeration for night time river water samples still posed higher acute toxicity showing TUa respectively of $0.13 \pm 0.02,0.44 \pm 0.13$, and $1.04 \pm 0.13$. These showed that aeration type has different capacity in lowering water toxicity and improving water quality. Study suggested that contaminated river water quality and toxicity could be improved by aeration processes.
\end{abstract}

\section{Introduction}

River water pollution is commonly found in many developing countries. In Indonesia Citarum River is known for its pollution. Citarum River is located in West Java Province, with around $269 \mathrm{~km}$ length from central southern part of West Java to the north part of the province. Citarum River is an important river that supports more than 25 million people in the region. However, it is considered highly polluted due to the discharges of various human activity along its way to the Java Sea. One tributary in the upperstream of Citarum River, i.e. Cikakembang River, which is located in Majalaya district where many industries predominantly textiles discharge their wastes into the river. There are at least 56 industries that discharge their wastes or effluents into the Citarum River in Majalaya region and 22 of them are discharging into Cikakembang River [1].

Cikakembang River water quality has been deteriorated and exceeded governmental standards for COD, TSS, phenol, copper, lead, phosphate, and sulphide [2]. Biodiversity index assessment for makrozoobenthos in Cikakembang River was found at 0.85 [3]. The acute toxicity (TUa, i.e. acute toxicity unit) on Daphnia magna of the river water were fluctuated ranged between 0.2 to 6 . TUA higher than 1 was considered high in toxicity [2]. Therefore, the pollution occurred in the Cikakembang River has been unacceptable and required any effort to reduce the pollution levels. Revitalization technology is needed to

\footnotetext{
* Corresponding author: indahrss@tl.itb.ac.id
}

improve the quality of the river. Aeration technique is one of the potential method that commonly use in water treatment. Aeration will increase dissolved oxygen levels so that self purification in the river water could be obtained [4]. Therefore, this study was aimed to evaluate the effect of aeration process on river water quality and toxicity. It was expected that aeration could improve the river water quality and furthermore reduce the toxicity.

\section{Methodology}

River water samples were collected from a point at Cikakembang River (with coordinate of 0703 '6,8'S107 $45^{\prime} 5,5^{\prime \prime} \mathrm{E}$ ), three times during the period of December 2017 and January 2018. Each sampling consisted with day and night time sampling collection. Water quality parameters analyzed were TSS, TDS, COD, nitrate, phosphate, nitrite, phenol which were carried out according to Standard Methods.for the examination of water and wastewater (SMEWW). Acute toxicity test of LC50 $96 \mathrm{hrs}$ on Daphnia magna was measured to obtain TUa (toxicity unit acute) value. Toxicity test conducted was based on USEPA [6].

Three types of aeration methods namely mechanical, hydraulic, and diffused air were studied in laboratory scale. Hydraulic aeration was carried out by pumping the water up to an 8 steps stair like cascade with width, height, and length of $20 \mathrm{~cm}, 20 \mathrm{~cm}$, and $30 \mathrm{~cm}$ 
respectively. The cascade aerator was equipped with flow meter and pump with capacity of $15 \mathrm{~L} / \mathrm{min}$, and run for around 10 minutes. The water fall from cascade was then collected. Mechanical aeration was carried out on a jar test equipped with pedal stirrer at $50 \mathrm{rpm}$ for 2 hours in $1 \mathrm{~L}$ container. Diffuse aeration was conducted in $0.2 \mathrm{x}$ $0.2 \times 0.2 \mathrm{~m}^{3}$ acrylic container with $2.5 \mathrm{~cm}$ length and 1 $\mathrm{cm}$ diameter of stone diffuser using an aquarium pump Recent type RC-999, for 2 hours. During aeration, dissolved oxygen was measured by Lutron DO meter type DO-5512SD. DO was continuously measured and logged in the instrument.

Acute toxicity of LC50-96 hrs on Daphnia magna was performed according to whole effluent toxicity test static non-renewal method. LC50 value was obtained using Probit analysis which then converted to TUa (acute toxicity unit) value with the following equation:

$$
T U a=1 / L C 50 \times 100 \%
$$

The acute toxicity test included culturing of the Daphnia magna, range finding test, definitive test, using 5 neonates in each $40 \mathrm{~mL}$ volume tested container with 5 level concentrations of river water dillution. Mortality of D. magna was observed every $24 \mathrm{hrs}$ for total $96 \mathrm{hrs}$. A reference toxicant LC50 test was also carried out using sodium chloride as standard solution.

\section{Results and Discussion}

\subsection{Quality of Cikakembang River}

The Cikakembang River water quality had exceeded the governmental standard of PP No. 82 year 2001 for water body quality Class II for some parameters namely TDS, TSS, DO, COD, nitrite, phenol, and total phosphate. Results of water quality measurement was shown in Table 1. Temperature of the river water was considered high $\left(>31{ }^{\circ} \mathrm{C}\right)$ as normal temperature of the river in that area were usually in the range of $23-25^{\circ} \mathrm{C}$. This was not surprising as high temperature of river water was also detected in previous study $[5,2]$. Textile industry may involve some processes that resulted in high temperature of its waste.

The study results also showed that the quality of river water at night was worse than at day time samples. Almost all parameters condition from night collected water samples was higher than those from day time collected samples. This was also noticed from previous studies that the water quality of the river at night was more polluted [5]. Some industries were predicted to secretly discharged their wastes at night. The river water flowrate at night was also found higher than in the morning and at noon or daytime. Every two hourly flowrate measurement on August 2015 showed minimum flowrate at daytime of $0.199 \mathrm{~m} 3 / \mathrm{s}$ at around $10.30 \mathrm{am}$, and maximum of $0.619 \mathrm{~m} 3 / \mathrm{s}$ at midnight. The average flowrate of Cikakembang River was estimated of $0.43 \mathrm{~m} 3 / \mathrm{s}$ [5]. Based on monthly monitoring data collected by Environmental Agency of Bandung
Regency, the average flowrate of Cikakembang River in the period of January 2015 to May 2017 was $0.41 \mathrm{~m} 3 / \mathrm{s}$ [14].

Table 1. Water quality of Cikakembang River.

\begin{tabular}{|c|c|c|c|}
\hline Parameters & Unit & Day time & Night time \\
\hline Temperature & ${ }^{\circ} \mathrm{C}$ & $32.73 \pm 1.05$ & $31.4 \pm 1.2$ \\
\hline TDS & $\mathrm{mg} / \mathrm{l}$ & $1210 \pm 303.4^{*}$ & $1557 \pm 163.2 *$ \\
\hline TSS & $\mathrm{mg} / 1$ & $63.58 \pm 5.1^{*}$ & $92.6 \pm 34.8^{*}$ \\
\hline Salinity & ppt & $0.6 \pm 0.12$ & $1.03 \pm 0.08$ \\
\hline $\mathrm{pH}$ & - & $8.5 \pm 0.2$ & $8.9 \pm 0.1$ \\
\hline DO & $\mathrm{mg} / 1$ & $1.25 \pm 0.1^{*}$ & $1.35 \pm 0.2 *$ \\
\hline COD & $\mathrm{mg} / \mathrm{l}$ & $108.8 \pm 41.5^{*}$ & $210.6 \pm 59.2^{*}$ \\
\hline Ammonium & $\mathrm{mg} / 1$ & $0.22 \pm 0.04$ & $0.4 \pm 0.1$ \\
\hline Nitrite & $\mathrm{mg} / \mathrm{l}$ & $0.3 \pm 0.1 *$ & $0.2 \pm 0.08^{*}$ \\
\hline Nitrate & $\mathrm{mg} / 1$ & $0.04 \pm 0.003$ & $0.05 \pm 0.01$ \\
\hline Phenol & $\mathrm{mg} / \mathrm{l}$ & $0.04 \pm 0.02$ & $0.05 \pm 0.02$ \\
\hline $\begin{array}{c}\text { Total } \\
\text { Phosphate }\end{array}$ & $\mathrm{mg} / \mathrm{l}$ & $0.3 \pm 0.09^{*}$ & $0.240 .04 *$ \\
\hline
\end{tabular}

*= exceeding the standard

Aeration application successfully increased dissolved oxygen concentration in the water. From the three aeration methods studied, cascade aeration showed the highest DO enhancement up to seven times. Meanwhile, both mechanical aeration and diffuse aeration raised DO concentration up to 2 and 3 times. The increase of DO in cascade was too high than the DO saturation value at around room temperature condition. It was not considered accurate due to the nature of mixing of waterfall and the DO meter capacity and sensitivity. However, DO concentration in mechanical and diffused air aeration showed more realistic results. Then, this proved that aeration applied could effectively increase DO concentration and could lead to higher degradation rate of pollutants in the water.

Effects of aeration on water quality of studied parameters were shown in Fig. 1- Fig. 8. Aeration changed the TDS, as the oxidation progresses, the ions only changed into other ions so that they remained measured as TDS [7]. The factor causing the increase in $\mathrm{pH}$ was the oxidation of $\mathrm{CO}_{2}$ present in the form of carbonic acid in water to form $\mathrm{CO}_{2}$ in the gas phase. The loss of the carbonic acid may increase the $\mathrm{pH}$ of the water [8].

Nitrate was a form of nitrogen compound with the highest oxidation rate, so aeration increased nitrate concentration in water. As with nitrates, ammonium was a nitrogen compound that could be oxidized. After aeration, ammonium turned into a higher oxidation compound form such as nitrite and nitrate. This 
processes is influenced by several environmental factors such as temperature, salinity, light, organic concentration, substrate concentration (ammonium and nitrite), $\mathrm{pH}$, and oxygen concentration. At the same time, organic nitrogen compounds could be oxidized to ammonium [9]. Total phosphate removed after aeration. Polyphosphates was hydrolyzed to form orthophosphates, while phosphates in orthophosphate form were difficult to oxidize.

Phenol in river water was below the standard. However, aeration slightly reduced phenol that was considered toxic to most organisms. Furthermore, COD removal after aeration processes varied around $26 \%$ to $50 \%$. The highest removal occurred in diffuse aeration method for the day sample, and the lowest removal occurred in cascade aeration method for the night sample. Aeration supplied oxygen to oxidize organic materials, and reducing COD concentration.

The water quality of parameters studied was shown to change after aeration. The study suggested that aeration improved the river water quality. Most parameters measured performed improvement of the quality. Nitrate however increased ater aeration due to oxidation of ammonium and nitrate was the final product of nitrogen form oxidation. On the other hand, nitrite was the intermediate product that was affected by ammonium and nitrate process of nitrification.

Textile industry discharged waste with high $\mathrm{pH}$ and this $\mathrm{pH}$ in the river was lower after aeration.

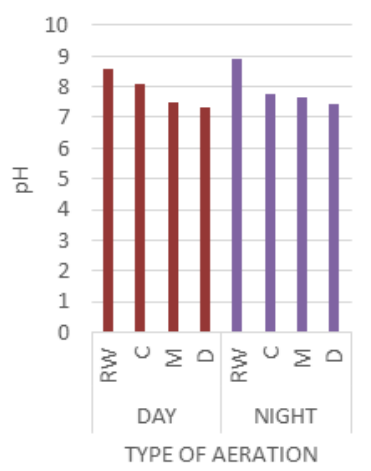

Fig. 1. $\mathrm{pH}$ in river water and after aeration $(\mathrm{RW}=$ river water, $\mathrm{C}=$ cascade, $\mathrm{M}=$ mechanical, $\mathrm{D}=$ diffuser)

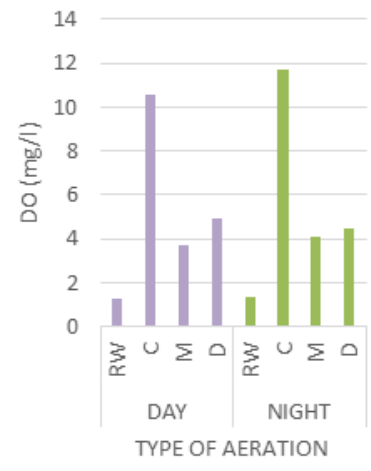

Fig. 2. $\mathrm{DO}$ in river water and after aeration $(\mathrm{RW}=$ river water, $\mathrm{C}=$ cascade, $\mathrm{M}=$ mechanical, $\mathrm{D}=$ diffuser)

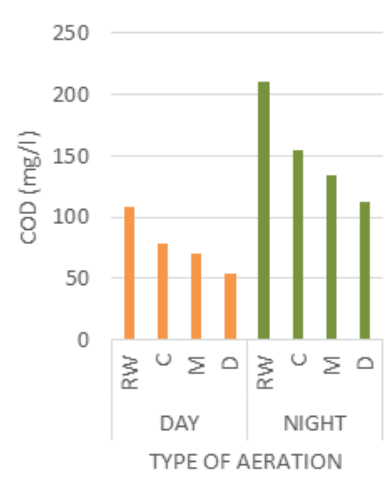

Fig. 3. $\mathrm{COD}$ in river water and after aeration $(\mathrm{RW}=$ river water, $\mathrm{C}=$ cascade, $\mathrm{M}=$ mechanical, $\mathrm{D}=$ diffuser)

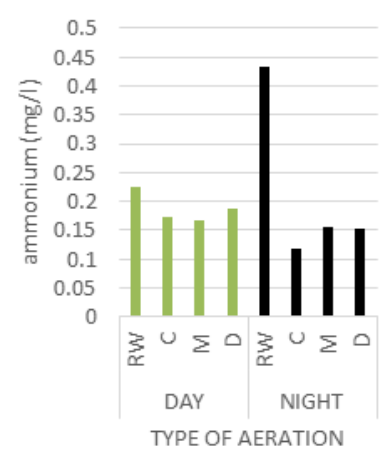

Fig. 4. Ammonium in river water and after aeration $(\mathrm{RW}=$ river water, $\mathrm{C}=$ cascade, $\mathrm{M}=$ mechanical, $\mathrm{D}=$ diffuser)

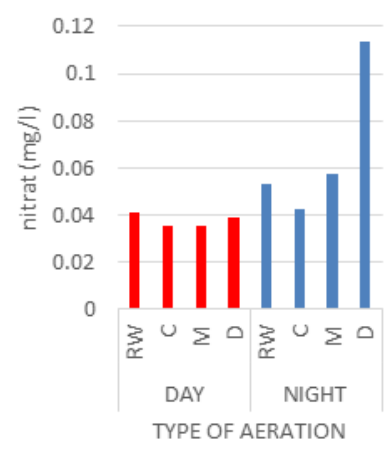

Fig. 5. Nitrate in river water and after aeration ( $\mathrm{RW}=$ river water, $\mathrm{C}=$ cascade, $\mathrm{M}=$ mechanical, $\mathrm{D}=$ diffuser)

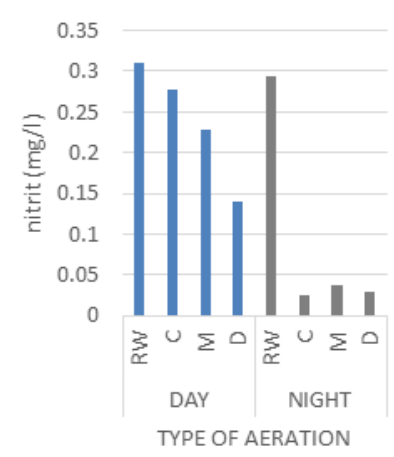

Fig. 6. Nitrite in river water and after aeration $(\mathrm{RW}=$ river water, $\mathrm{C}=$ cascade, $\mathrm{M}=$ mechanical, $\mathrm{D}=$ diffuser) 


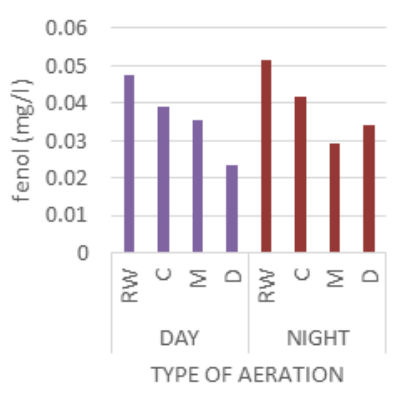

Fig. 7. Phenol in iver water and after aeration ( $\mathrm{RW}=$ =river water, $\mathrm{C}=$ cascade, $\mathrm{M}=$ mechanical, $\mathrm{D}=$ diffuser)

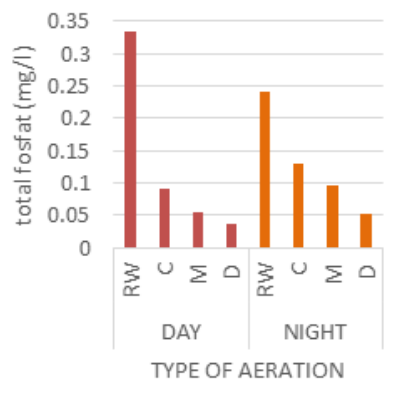

Fig. 8. Total phosphate in river water and after aeration ( $\mathrm{RW}=$ river water, $\mathrm{C}=$ cascade, $\mathrm{M}=$ mechanical, $\mathrm{D}=$ diffuser)

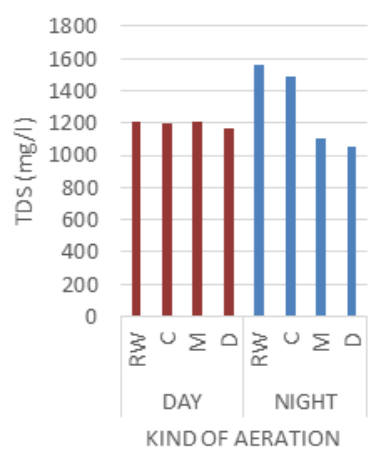

Fig. 9. TDS in river water and after aeration $(\mathrm{RW}=$ river water, $\mathrm{C}=$ cascade, $\mathrm{M}=$ mechanical, $\mathrm{D}=$ diffuser $)$

\subsection{Toxicity of Cikakembang River}

The results of toxicity measurement as indicated with TUa value was shown in Table 2. According to Persoone [10], TUa value of lower than 0.4 was considered nontoxic. The study showed the highest TUa value of Cikakembang River water was $1,77 \pm 0,12$, which indicated the water was toxic. Toxicity test also resulted that toxicity of river water at day time samples were lower than those at night samples that contained TUa $>1$ or considered toxic. Average toxicity of river water showed TUa of samples collected at daytime was $0.467 \pm 0.12$, and TUa of night samples was $1.36 \pm 0.3$. Table 2 also exhibited different types of aeration exhibited different toxicity reduction. After aeration with cascade treatment, the TUa value decreased up to $0.30 \pm 0.2$. While mechanical and diffuse aeration, TUa value decreased to $0.08 \pm 0.04$ and $0.01 \pm 0.002$ respectively. Diffuse aeration revealed the most significance effect in lowering TUa value. Aerator efficiency was depended on the bubble size. Higher amount of bubbles and smaller size of bubbles led to more effective aeration. Meanwhile, in mechanical aeration the efficiency was higher because of good circulation and mixture performed uniform air distribution.

Table 2. TUA value of river water and after aeration application

\begin{tabular}{|c|c|c|c|}
\hline \multicolumn{2}{|c|}{ Samples } & River water & Cascade \\
\hline \multirow{3}{*}{ Day } & 1 & $0.47 \pm 0.11$ & $0.30 \pm 0.2$ \\
\cline { 2 - 4 } & 2 & $0.46 \pm 0.01$ & $0.13 \pm 0.05$ \\
\cline { 2 - 4 } & 3 & $0.47 \pm 0.02$ & $0.37 \pm 0.18$ \\
\hline \multirow{3}{*}{ Night } & 1 & $1.02 \pm 0.18$ & $0.85 \pm 0.26$ \\
\cline { 2 - 4 } & 2 & $1.30 \pm 0.4$ & $1.15 \pm 0.03$ \\
\cline { 2 - 4 } & 3 & $1.77 \pm 0.12$ & $1.14 \pm 0.5$ \\
\hline \multicolumn{2}{|c|}{ Samples } & Mechanical & Difuser \\
\hline \multirow{3}{*}{ Day } & 1 & $0.12 \pm 0.09$ & $0.10 \pm 0.09$ \\
\cline { 2 - 4 } & 2 & $0.08 \pm 0.04$ & $0.01 \pm 0.002$ \\
\cline { 2 - 4 } & 3 & $0.24 \pm 0.04$ & $0.08 \pm 0.07$ \\
\hline \multirow{3}{*}{ Night } & 1 & $0.22 \pm 0.09$ & $0.12 \pm 0.09$ \\
\cline { 2 - 4 } & 2 & $0.46 \pm 0.01$ & $0.10 \pm 0.02$ \\
\cline { 2 - 4 } & 3 & $0.66 \pm 0.11$ & $0.17 \pm 0.04$ \\
\hline
\end{tabular}

The toxicity measurement validity required comparison to a known chemical toxicity. This study used $\mathrm{NaCl}$ as reference toxicant. The LC50 of $\mathrm{NaCl}$ showed average LC50 of $4.63 \mathrm{mg} / \mathrm{L}$ and this was still in accordance with other studies of LC50 NaCl results in the range of 3.6 $\mathrm{g} / \mathrm{L}$ to $4.7 \mathrm{~g} / \mathrm{L}$ [11]. This was suggested that the toxicity results in this study was considered comparable to acute toxicity testing elsewhere.

Textile wastes commonly contained coloring agents or dyes with various organic composition. The dye was contributed to give toxic effects on organisms [12]..This study of aeration method could improve the river water quality and reduced its toxicity. Toxicity reduction of each aeration methods was depicted in Table 4. It showed that diffuser aeration gave the highest toxicity reduction. Aeration changed the $\mathrm{pH}$, oxygen content, and performed oxidation of various chemical reaction. Furthermore, these interacted with tested organisms to give its impact on organism survival.

To evaluate the parameters affecting the toxicity a mathematical model was applied. Table 3 showed mathematical model of factors affecting toxicity for each aeration method. Salinity, total phosphate, COD, TSS, and nitrite were chemical parameters indicated by statistical analysis to affect the toxicity. However, only 
in diffuser method the toxicity showed statistically significant relationship with nitrite. Other aeration method predicted that salinity, total phosphate, and COD were factors affecting toxicity but not statiscally significant $(\mathrm{p}>0.05)$. Survival ability of $D$. magna required specific range of temperature of $18-26^{\circ} \mathrm{C}, \mathrm{pH}$ at the range of $6.5-9.5$, and DO of $>3 \mathrm{mg} / \mathrm{L}$ [6]. Salinity was the responsible parameter in the survival of Daphnid population in natural microcosm [13]. COD indicated organic content of water or wastewater, and this could originate from various kinds of organics such as found in textile waste, pesticides, domestic wastes, and many anthropogenics. Mixture of chemical content represented in COD posed potential source of toxicity to tested organisms. However, further analysis was required to investigate types of organics found in the river water studied.

Comparing the toxicity reduction for all types of aeration, it was shown that diffused air method offered higher toxicity reduction (Table 4). This was also in accordance with the chemical parameter improvement of river water quality. DO concentration as the aeration product was the improtant key factor to improve and revitalize or restoration of the polluted river water.

Table 3. Model of chemical parameters affecting toxicity

\begin{tabular}{|c|c|l|c|}
\hline $\begin{array}{c}\text { Aeration } \\
\text { methods }\end{array}$ & $\begin{array}{c}\boldsymbol{p} \text { - } \\
\text { value }\end{array}$ & \multicolumn{1}{|c|}{ Model equation } & $\mathbf{R}^{2}$ \\
\hline Cascade & 0,176 & $\begin{array}{l}\mathrm{y}=-1,220+27,678(\mathrm{TP})- \\
1,953(\mathrm{Sal})+0,002(\mathrm{COD})\end{array}$ & 0,879 \\
\hline Mechanical & 0,103 & $\begin{array}{l}\mathrm{y}=-0,036+0,456(\mathrm{Sal})- \\
0,006(\mathrm{TSS})+0,003(\mathrm{COD})\end{array}$ & 0,930 \\
\hline Diffuser & 0,019 & $\mathrm{y}=0,47-0,589(\mathrm{Nitrit})$ & 0,781 \\
\hline
\end{tabular}

Table 4. Toxicity reduction of aeration types (\%)

\begin{tabular}{|c|c|c|}
\hline $\begin{array}{c}\text { Types of } \\
\text { Aeration }\end{array}$ & $\begin{array}{c}\text { Day } \\
\text { Sample }\end{array}$ & $\begin{array}{c}\text { Night } \\
\text { Sample }\end{array}$ \\
\hline Cascade & $43 \pm 26$ & $21 \pm 13$ \\
\hline Mechanical & $69 \pm 18$ & $69 \pm 9$ \\
\hline Diffuser & $87 \pm 10$ & $90 \pm 2$ \\
\hline
\end{tabular}

Selection of appropriate aeration methods applied in river water restoration were then should be evaluated related to many factors such as the engineering application techniques, energy requirement, operation \& maintenance, and levels of aeration expected.

\section{Conclusions}

Waste discharges from human activity along the river resulted on deterioration of the river water quality.
Some water quality parameters in Cikakembang River had exceeded the governmental standards, and this had occurred for many years, Improvement of river water quality should be done properly. Application study of three aeration methods showed that aeration reduced the pollution levels, by increasing river water quality and reducing its toxicity on D. magna, by decreasing TUa values. Aeration method was potential to be used in field. The selection of aeration types applied was however depended on its field application suitability. Further study to evaluate the application of aeration for revitalization and restoration of polluted river was then strongly suggested.

The acknowledgement was borne to Riset ITB Grant 2017 that supported this study.

\section{References}

1. BPLHD, Monitoring Water Quality Report of Citarum River, West Java Province - Environmental Protection Agency (2012)

2. I.R.S. Salami, T. Maulini, M. Iriany, D. Roosmini. Ecotoxicological effects of textile waste effluents on Daphnia magna and Allium cepa in the upperstream segment of Citarum River, West Java, Indonesia, Proceeding of the 11th International Symposium of South East Asian Water Environment (SEAWE), Bangkok (2014)

3. M. Iriany. Citarum River quality assessment using makrozoobenthos diversity and toxicity to Allium cepa. Master Thesis, Department of Environmental Engineering, ITB (2014)

4. Y. Sheng, Q. Yingxuan. D. Chaofeng, S. Qiyao, R.J.G. Mortimer. A Combined Application of Different Engineering and Biological Techniques to Remediate a Heavily Polluted Water. J. Ecol. Eng., 57, pp. 1-7 (2013)

5. F.A. Ifachril. Effectivity of Phytoremediation on River Water Receiving Textile Wastes (Case Study: Cikakembang River, Majalaya, Kabupaten Bandung), Final Project, Department of Environmental Engineering, ITB (2015)

6. EPA. Methods for Measuring the Acute Toxicity of Effluents and Receiving Waters to Freshwater and Marine Organisms. Environmental Protection Agency. USA (2002)

7. G.S. Schuytema, A.V. Nebeker, T.W. Stutzman. Salinity Tolerance of Daphnia magna and Potential Use of Estuarine in Sediment Toxicity Test. Arch.of Env. Cont. and Tox., 32, 194-198 (1997)

8. J.A. Grottum, M. Staurnes, T. Sigholt. Effect of Oxygenation, Aeration, and $\mathrm{pH}$ control on Water Quality and Survival of Turbot, Scophthalmus maximus, kept at High Densities During Transport. Aquaculture Res., 29, 159-164 (1997)

9. S. Manahan.. Environmental Chemistry, 8th Edition. Florida: CRC Press. (2005) 
10. G. Persoone, B. Marsalek, I. Blinova, A. Törökne, D. Zarina, L. Manusadzianas, G. Nalecz-Jawecki, L. Tofan, N. Stepanova, L. Tothova, and B. Kolar. A Practical and User-friendly Toxicity Classification System with Microbiotests for Natural Waters and Wastewaters. Env. Tox., 18, 395-402 (2013)

11. C. Wang, C. Liang, H. Yeh. Aquatic Acute Toxicity Assessments of Molybdenum to Daphnia magna. Chemosphere, 147, 82-87 (2015)

12. R. Croce, F. Cina, A. Lombardo, G. Crispeyn, C.I. Capelli, M. Vian, S. Maiorana, E. Benfenati, D. Baderna. Aquatic Toxicity of Several Textile Dye Formulations; Acute and Chronic Assays with Daphnia Magna and Raphidochelis Subcapitata, J. of Ecotox. and Env.Safety, 144, pp. 79-87(2017)

13. C. Duchet, Th. Caquet, E. Franquet, C. Lagneau, L. Lagadiic. Influence of environmental Factors on the Response of a Natural Population of Daphnia magna (Crustacea: : Cladocera) to Spinosiad and Baccilus thuringiensis israeliensis in Mediterranean Coastal wetlands. Env. Poll.158, 5, pp. 1825-1833 (2010)

14. W.T. Marco. The Design of River Revitalization by Constructed Wetland in Cikakembang River, Majalaya, Final Project, Department of Environmental Engineering, ITB (2019) 